Biogeosciences, 10, 839-849, 2013

www.biogeosciences.net/10/839/2013/

doi:10.5194/bg-10-839-2013

(C) Author(s) 2013. CC Attribution 3.0 License.

\title{
Influence of terrestrial inputs on continental shelf carbon dioxide
}

\author{
L.-Q. Jiang ${ }^{1,{ }^{*}}$, W.-J. Cai ${ }^{1}{ }^{\text {** }}$, Y. Wang ${ }^{1}$, and J. E. Bauer ${ }^{2}$ \\ ${ }^{1}$ Department of Marine Sciences, The University of Georgia, Athens, Georgia 30602, USA \\ ${ }^{2}$ Department of Evolution, Ecology, and Organismal Biology, The Ohio State University, Columbus, Ohio 43212, USA \\ *Present address: Cooperative Institute for Climate and Satellites, Earth System Science Interdisciplinary Center, \\ University of Maryland, College Park, Maryland 20740, USA \\ ** Present address: School of Marine Science and Policy, University of Delaware, Newark, Delaware 19716, USA
}

Correspondence to: W.-J. Cai (wcai@udel.edu)

Received: 2 July 2012 - Published in Biogeosciences Discuss.: 27 July 2012

Revised: 6 December 2012 - Accepted: 19 December 2012 - Published: 7 February 2013

\begin{abstract}
The US South Atlantic Bight (SAB) is a lowlatitude shallow continental shelf bordered landward by abundant salt marshes and rivers. Based on previously published data on sea surface partial pressure of carbon dioxide $\left(p \mathrm{CO}_{2}\right)$ and new dissolved inorganic carbon (DIC) and dissolved organic carbon (DOC) data, a model analysis is presented to identify and quantify the contributions of various terrestrial carbon inputs on $\mathrm{SAB}$ sea surface $p \mathrm{CO}_{2}$. After removal of $p \mathrm{CO}_{2}$ variations due to annual temperature variability and air-sea gas exchange from the in situ $p \mathrm{CO}_{2}$, the temperature- and gas-exchange-corrected $p \mathrm{CO}_{2}$ (TG-corrected $p \mathrm{CO}_{2}$ ) is derived. Contributions from rivers, salt marshes, and the continental shelf to the TGcorrected $p \mathrm{CO}_{2}$ are then calculated. Our findings demonstrate that although additions of $\mathrm{CO}_{2}$ from within shelf waters (i.e., $\Delta p \mathrm{CO}_{2}$ (shelf)) were the greatest of the three components and underwent the largest seasonal changes, $\Delta p \mathrm{CO}_{2}$ (shelf) showed smaller onshore-offshore gradients than rivers and marshes. In contrast, $\mathrm{CO}_{2}$ contributions from river $\left(\triangle p \mathrm{CO}_{2}\right.$ (river)) and salt marsh $\left(\triangle p \mathrm{CO}_{2}\right.$ (marsh)) components were greatest closest to the coast and decreased with distance offshore. In addition, the magnitude of $\Delta p \mathrm{CO}_{2}$ (marsh) was about three-fold greater than $\Delta p \mathrm{CO}_{2}$ (river). Our findings also revealed that decomposition of terrestrial organic carbon was an important factor regulating the seasonal pattern of $p \mathrm{CO}_{2}$ on the inner shelf. Despite large uncertainties, this study demonstrates the importance of terrestrial inputs, in particular those from coastal wetlands, on coastal ocean $\mathrm{CO}_{2}$ distributions.
\end{abstract}

\section{Introduction}

Continental shelves play a key role in the global carbon cycle by linking terrestrial, marine and atmospheric systems (Mackenzie, 1991; Smith and Hollibaugh, 1993). Despite their relatively small size $(\sim 7-8 \%$ of the global ocean surface area), continental shelves sustain disproportionately high rates of primary production, remineralization, and organic carbon burial (Walsh, 1988; Wollast, 1993; Gattuso et al., 1998; de Hass et al., 2002). Recent studies have further shown that continental shelves are a globally important sink of atmospheric carbon dioxide $\left(\mathrm{CO}_{2}\right)$ (Borges et al., 2005; Cai et al., 2006; Chen and Borges, 2009).

The majority of continental shelves, in particular those that are both wide and aligned with a western boundary current, can be divided into two zones: the proximal (i.e., inner) shelf that is strongly impacted by land, and the distal (i.e., middle and outer) shelf that is influenced to a greater extent by open ocean waters (Rabouille et al., 2001). Relative to the distal shelf, the proximal shelf generally shows much steeper biogeochemical gradients owing to its proximity to inputs from land, including rivers, estuaries and salt marshes. Therefore, higher resolution surveys are warranted to understand the biogeochemical processes on the proximal shelf, although it has often been neglected in continental shelf $\mathrm{CO}_{2}$ studies.

Continental shelves are strongly impacted by inputs of nutrients and organic and inorganic carbon from land (Thomas et al., 2004). As a result of nutrient inputs, proximal continental shelves typically sustain a relatively high level of biological productivity (Walsh, 1988; Wollast, 1993), which may draw down $\mathrm{CO}_{2}$. However, this effect may be 
counteracted by enhanced heterotrophic activity supported by organic carbon input from land (Bauer and Bianchi, 2011; Bianchi and Bauer, 2011). In addition, direct inorganic carbon input from river waters plays an important role in enhancing $p \mathrm{CO}_{2}$ of shelf waters (Raymond et al., 2000; Borges et al., 2006; Jiang et al., 2008b). Tidal exchange with intertidal marshes (Wang and Cai, 2004) and mangroves (Borges et al., 2003) may also raise $p \mathrm{CO}_{2}$ in continental shelf waters. Understanding the roles of these different processes in driving carbon and $\mathrm{CO}_{2}$ exchanges in shelf waters is critical for establishing both the relative contributions of each to coastal carbon budgets and for predicting future changes due to changes in climate, hydrology and coastal circulation.

In order to differentiate the various components contributing to shelf carbon and $\mathrm{CO}_{2}$ sources and fluxes, we investigated the South Atlantic Bight (SAB) off the southeastern United States. The SAB is a low-latitude shallow continental shelf bordered landward by abundant salt marshes and river discharge and seaward by a major western boundary current, the Gulf Stream. This unique geographical location offers well-defined and distinct landward and seaward components. A recent study has shown that while the distal SAB shelf is an atmospheric $\mathrm{CO}_{2}$ sink of $-1.3 \mathrm{~mol} \mathrm{~m}^{-2} \mathrm{yr}^{-1}$, the proximal SAB shelf is a source of $1.2 \mathrm{~mol} \mathrm{~m}^{-2} \mathrm{yr}^{-1}$ (Jiang et al., 2008a). The goal of this study is to differentiate and quantify the contributions of the annual temperature cycle, airsea gas exchange, and inputs from rivers, salt marshes and within shelf waters to sea surface $p \mathrm{CO}_{2}$ in this region. Evaluating the roles of these different drivers will contribute to the understanding of carbon dioxide dynamics in the coastal ocean. The present study is based on $\mathrm{CO}_{2}$ data previously reported in Jiang et al. (2008a), and new dissolved inorganic carbon (DIC) and dissolved organic carbon (DOC) data from the same cruises.

\section{Study site and methods}

\subsection{Site description}

The SAB continental shelf has an average depth of only $30 \mathrm{~m}$ and is $50-75 \mathrm{~m}$ deep at the shelf break (Menzel, 1993). The Gulf Stream flows northward along the shelf break (Fig. 1). The shorelines of Georgia and South Carolina are characterized by extensive salt marshes $\left(3000 \mathrm{~km}^{2}\right.$, Alexander et al., 1986). Tidal currents flood and drain intertidal salt marshes twice daily and transport materials between the marshes and the SAB (Hopkinson, 1985). Most rivers in this region are located in the central and northern part of the shelf. Discharge usually peaks in February-April, and a secondary peak may occur in fall, with a total annual discharge of about $66 \mathrm{~km}^{3}$ ( $\sim 2.7 \%$ of the SAB volume) (Menzel, 1993). Groundwater may also represent important additional inputs of water and other materials to the shelf waters (Moore, 2007 and references therein).

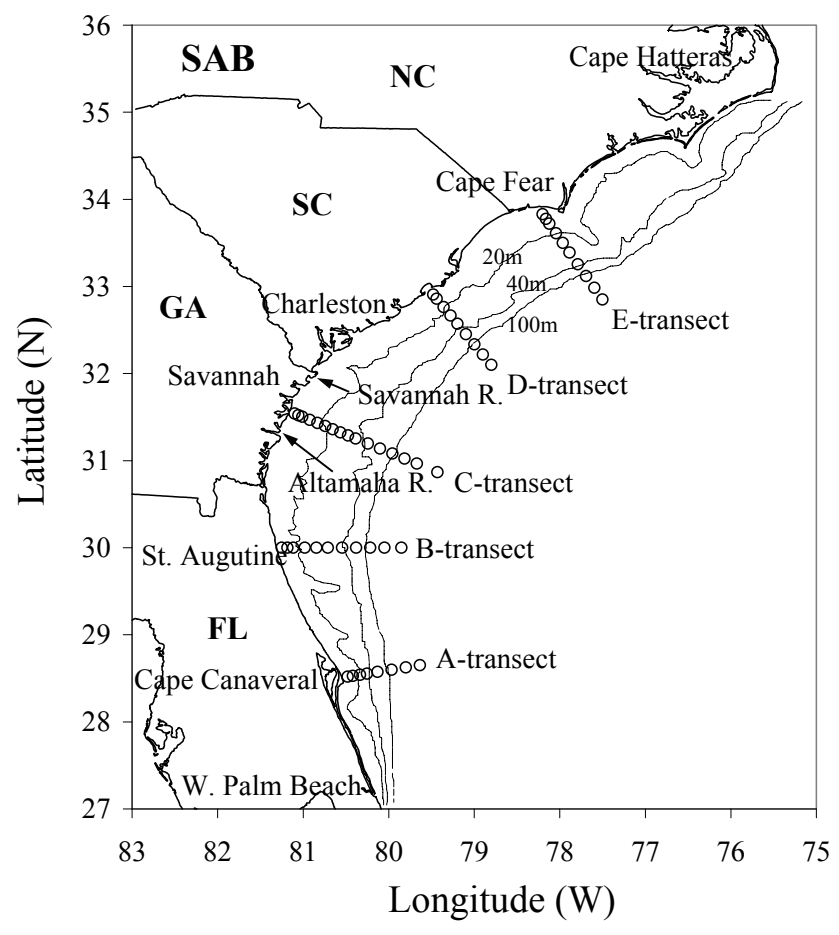

Fig. 1. Study area in the US South Atlantic Bight between Cape Lookout, North Carolina, and Cape Canaveral, Florida. Open circles indicate sampling stations, between the shoreline and extending to $\sim 500 \mathrm{~m}$ water depth.

A coastal frontal zone (CFZ), formed by a pressure gradient induced by freshwater discharge, frequently occurs at $10-30 \mathrm{~m}$ isobaths, about $10-30 \mathrm{~km}$ offshore on the SAB shelf (Blanton, 1981). For simplicity, we refer to the shelf shoreward the CFZ as the proximal SAB (roughly equivalent to the inner shelf, as defined in Jiang et al., 2008a), and the shelf seaward the $\mathrm{CFZ}$ as the distal SAB (roughly equivalent to the middle and outer shelf).

The proximal SAB (inner shelf) is turbid as a result of material transport from rivers and exchange with intertidal salt marshes (Pomeroy et al., 2000). Primary production here is mainly driven by nutrients recycled in the water column (Dunstan and Atkinson, 1976; Hanson et al., 1990) and from sediments (Jahnke et al., 2005). On the distal SAB shelf (middle and outer shelf), water clarity increases dramatically, and the euphotic zone extends to the seafloor (Nelson et al., 1999). Production here is strongly influenced by intrusions induced by Gulf Stream frontal eddies (Atkinson et al., 1984).

\subsection{Sampling}

A whole-shelf survey consisting of five onshore-offshore transects (A-, B-, C-, D-, and E-transects from south to north, Fig. 1) was carried out in the SAB during six cruises: 5-16 January 2005, 19-30 March 2005, 
27 July-5 August 2005, 7-17 October 2005, 16-21 December 2005, and 17-27 May 2006. Surface water $p \mathrm{CO}_{2}$, temperature, salinity, and atmospheric pressure at sea level were measured while underway during all cruises (Jiang et al., 2008a). Dissolved inorganic carbon (DIC) was sampled on all five transects except for December 2005, when only E-, $\mathrm{C}-$, and A-transects were covered. Dissolved organic carbon (DOC) samples were collected on D-, C-, and B-transects during January, March, and October 2005, and on all 5 transects during May 2006.

\subsection{Sample analysis}

DIC concentration was measured using an infrared $\mathrm{CO}_{2}$ detector-based DIC analyzer with a precision of $0.1 \%$ (Wang and Cai, 2004; Huang et al., 2012). DOC samples collected during the cruises of March, July, and October 2005 were measured in the Radiocarbon Laboratory of the Virginia Institute of Marine Science (VIMS) using a Shimadzu TOC5000A high-temperature Pt-catalyzed analyzer with a mean analytical error of $1.4 \mu \mathrm{mol} \mathrm{L}^{-1}$ (DeAlteris, 2007). DOC samples from May 2006 were analyzed in W. L. Miller's lab (University of Georgia) using a Shimadzu TOC-VCPN analyzer. Reference standards (deep Sargasso Sea seawater from D. A. Hansell's group at the University of Miami) and blanks (Milli-Q water) were analyzed every five samples to check accuracy and baseline stability and agreed within measurement error in both labs.

\subsection{Calculation of temperature- and gas-exchange-corrected $p \mathrm{CO}_{2}$}

In situ $p \mathrm{CO}_{2}$ often does not provide direct information about underlying biogeochemical processes, due to the fact that it is strongly impacted by temperature and air-sea gas exchange, as shown by Jiang et al. (2008a) in shallow coastal waters of $\mathrm{SAB}$. Here we remove $p \mathrm{CO}_{2}$ variations caused by the annual temperature cycle and air-sea gas exchange from the in situ $p \mathrm{CO}_{2}$. The remaining $p \mathrm{CO}_{2}$ is then assumed to be controlled primarily by biological activity and mixing. For simplicity, this temperature- and gas-exchange-corrected $p \mathrm{CO}_{2}$ will be called TG-corrected $p \mathrm{CO}_{2}$ hereafter, and can be calculated as

$$
\begin{aligned}
& \left.p \mathrm{CO}_{2} \text { (TG-corrected }\right)=p \mathrm{CO}_{2} \text { (in situ) }-\left[\Delta p \mathrm{CO}_{2}\right. \text { (temp) } \\
& \left.+\Delta p \mathrm{CO}_{2} \text { (air-sea) }\right),
\end{aligned}
$$

where $p \mathrm{CO}_{2}$ (TG-corrected) is the temperature- and gasexchange-corrected sea surface $p \mathrm{CO}_{2}$ (in $\mu \mathrm{atm}$ ), $p \mathrm{CO}_{2}$ (in situ) is the observed sea surface $p \mathrm{CO}_{2}, \Delta p \mathrm{CO}_{2}$ (temp) is the $p \mathrm{CO}_{2}$ change caused by temperature deviation from the annual mean temperature, and $\Delta p \mathrm{CO}_{2}$ (air-sea) is the $p \mathrm{CO}_{2}$ change due to air-sea gas exchange (also referenced to the annual mean sea surface temperature, SST).

Water temperature changes $p \mathrm{CO}_{2}$ both by shifting the inorganic carbon equilibrium and by altering solubility. As- suming other parameters are constant, $p \mathrm{CO}_{2}$ in water increases with increasing water temperature. The in situ $p \mathrm{CO}_{2}$ can be referenced to a constant temperature using the equation of Takahashi et al. $(1993,2002)$ :

$p \mathrm{CO}_{2}(\overline{\mathrm{SST}})=p \mathrm{CO}_{2}(\mathrm{in} \mathrm{situ}) \times \exp [0.0423 \times(\overline{\mathrm{SST}}-\mathrm{SST})]$,

where $\overline{\mathrm{SST}}$ is the annual mean SST, and $p \mathrm{CO}_{2}(\overline{\mathrm{SST}})$ is the $p \mathrm{CO}_{2}$ referenced to the annual mean SST. Once $p \mathrm{CO}_{2}(\overline{\mathrm{SST}})$ is calculated, the $p \mathrm{CO}_{2}$ change due to the temperature deviation from the annual mean SST is then calculated as

$\Delta p \mathrm{CO}_{2}($ temp $)=p \mathrm{CO}_{2}$ (in situ $)-p \mathrm{CO}_{2}(\overline{\mathrm{SST}})$.

It should be noted that the $p \mathrm{CO}_{2}$ change due to temperature deviation from the annual mean SST is relative to the temperature used for the calculation.

Because aqueous $\mathrm{CO}_{2}$ dissociates in water, the $p \mathrm{CO}_{2}$ change due to air-sea gas exchange cannot be estimated based on linear dilution of $\mathrm{CO}_{2}$ itself. Instead, it is calculated from changes in DIC and alkalinity (Riebesell et al., 2010). To that end, first, carbonate alkalinity (CA) is calculated from $p \mathrm{CO}_{2}$ and DIC at in situ temperature and salinity and then is held constant during the gas exchange process. Assuming the surface mixed layer in the SAB extends to the seafloor in all sampling months (as is the case for most of the cruises except July 2005), the DIC concentration prior to air-sea gas exchange (in $\mathrm{mmol} \mathrm{m}^{-3}$ ) can be calculated as

$\mathrm{DIC}_{\text {prior }}=\frac{\left.\text { DIC }(\text { perarea })_{\text {in situ }}-\Delta \text { DIC (air-sea }\right)}{\text { Depth }}$.

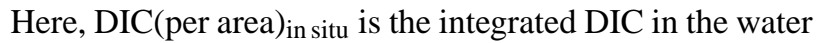
column, and $\triangle \mathrm{DIC}$ (air-sea) is the amount of DIC gain or loss caused by air-sea gas exchange (both in $\mathrm{mmol} \mathrm{m}^{-2}$ ). Positive $\triangle \mathrm{DIC}$ (air-sea) values indicate addition of $\mathrm{CO}_{2}$ to seawater through air-sea gas exchange. As a first-order approximation, a 30-day air-sea gas exchange time was used to calculate the $\triangle D I C$ (air-sea), as mean residence time of the entire SAB is 30-90 days (Atkinson et al., 1978; Moore, 2007). Additional information about how air-sea $\mathrm{CO}_{2}$ fluxes were calculated can be found in Jiang et al. (2008a). Once $\mathrm{DIC}_{\text {prior }}$ is calculated, $p \mathrm{CO}_{2}(\overline{\mathrm{SST}})_{\text {prior }}\left(p \mathrm{CO}_{2}\right.$ before air-sea gas exchange at the annual mean temperature) can be calculated from $\mathrm{DIC}_{\text {prior }}$ and $\mathrm{CA}$ at the annual mean temperature and the in situ salinity. $\Delta p \mathrm{CO}_{2}$ (air-sea) can then be calculated as the difference between $p \mathrm{CO}_{2}(\overline{\mathrm{SST}})$ and $p \mathrm{CO}_{2}(\overline{\mathrm{SST}})_{\text {prior }}$.

After both $\Delta p \mathrm{CO}_{2}$ (temp) and $\Delta p \mathrm{CO}_{2}$ (air-sea) have been estimated, TG-corrected $p \mathrm{CO}_{2}$ can be calculated from Eq. (1). As we can see, if $\Delta p \mathrm{CO}_{2}$ (temp) in Eq. (1) is substituted with the right-hand side of Eq. (3), the following is derived:

$p \mathrm{CO}_{2}(\mathrm{TG}-$ corrected $)=p \mathrm{CO}_{2}(\overline{\mathrm{SST}})-\Delta p \mathrm{CO}_{2}($ air-sea $)$. 
Thus, in addition to the definition given in Eq. (1), $p \mathrm{CO}_{2}$ (TG-corrected) may also be expressed as temperaturereferenced $p \mathrm{CO}_{2}$ corrected by the $p \mathrm{CO}_{2}$ change due to airsea gas exchange.

\section{$2.5 \mathrm{pCO}_{2}$ from river, marsh, and within-shelf sources}

Contributions of $p \mathrm{CO}_{2}$ (TG-corrected) can be divided into three components: $\Delta p \mathrm{CO}_{2}$ (river), the $p \mathrm{CO}_{2}$ change due to river inputs; $\Delta p \mathrm{CO}_{2}$ (marsh), the $p \mathrm{CO}_{2}$ change due to salt marsh inputs; and $\Delta p \mathrm{CO}_{2}$ (shelf), the $p \mathrm{CO}_{2}$ change due to biological activity and other processes on the shelf. $\Delta p \mathrm{CO}_{2}$ (river), $\Delta p \mathrm{CO}_{2}$ (marsh), and $\Delta p \mathrm{CO}_{2}$ (shelf) can be calculated by the following equations (Fig. 2):

$\Delta p \mathrm{CO}_{2}$ (river) $=p \mathrm{CO}_{2_{\mathrm{R}}}-p \mathrm{CO}_{2_{\text {base }}}$

$\Delta p \mathrm{CO}_{2}($ marsh $)=p \mathrm{CO}_{2_{\mathrm{R}+\mathrm{M}}}-p \mathrm{CO}_{2 \mathrm{R}}$

$\Delta p \mathrm{CO}_{2}$ (shelf) $=p \mathrm{CO}_{2}($ TG-corrected $)-p \mathrm{CO}_{2 \mathrm{R}+\mathrm{M}}$,

where $p \mathrm{CO}_{2}$ (base) is the $p \mathrm{CO}_{2}$ if the oceanic end-member is only diluted by freshwater that contains no DIC. $p \mathrm{CO}_{2}$ (base) can be calculated from its corresponding DIC $_{\text {base }}$ and $\mathrm{TA}_{\text {base }}$ that are calculated based on linear mixing of the open ocean end-members with the zero DIC and TA freshwater endmembers (Fig. 2). $p \mathrm{CO}_{2}$ is the $p \mathrm{CO}_{2}$ if the ocean endmember is only mixed with the river end-member. Similarly, $p \mathrm{CO}_{2 \mathrm{R}}$ can be calculated from its corresponding $\mathrm{DIC}_{\mathrm{R}}$ and $\mathrm{TA}_{\mathrm{R}}$ (Fig. 2), $p \mathrm{CO}_{2_{\mathrm{R}+\mathrm{M}}}$ is the $p \mathrm{CO}_{2}$ if the ocean endmember is only mixed with the nearshore end-member, which contains inputs from both the river and marsh. Again, $p \mathrm{CO}_{2 \mathrm{R}+\mathrm{M}}$ can be estimated from its corresponding $\mathrm{DIC}_{\mathrm{R}+\mathrm{M}}$ and $\mathrm{TA}_{\mathrm{R}+\mathrm{M}}$ using the same method (Fig. 2).

Table 1 shows the end-members used for the calculation. The river end-members were collected from Altamaha River (JayCee Landing in Jesup, Georgia, $31^{\circ} 67^{\prime} \mathrm{N}, 81^{\circ} 85^{\prime} \mathrm{W}$ ). Earlier studies have shown that Altamaha River provides a good representation of the river end-members in the South Atlantic Bight (Cai and Wang, 1998; Cai et al., 2010). The nearshore and open ocean end-members were chosen as the most nearshore and offshore stations of the central transect, respectively (Table 1).

The above method has been demonstrated to work well in estuaries (Jiang et al., 2008b). However, unlike estuaries, where mixing occurs between two end-members in a restricted area, the mixing processes on the continental shelf are far more complicated (Menzel, 1993). Mixing here occurs in both cross-shelf and along-shelf directions, and is complicated by the existence of the coastal frontal zone. These complex mixing processes make it challenging to choose which specific nearshore end-members to use. As a result, the selection of nearshore end-members could cause uncertainties in the estimated $\Delta p \mathrm{CO}_{2}$ (marsh)
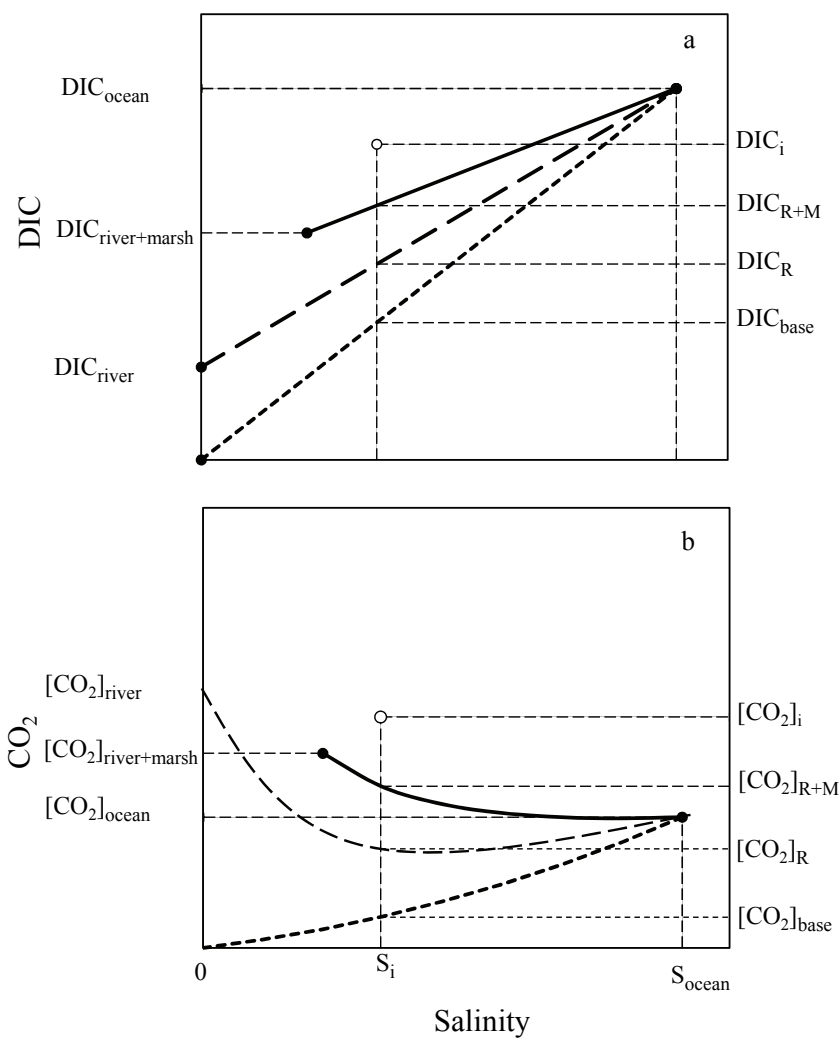

Fig. 2. Conceptual diagrams showing DIC and dissolved $\mathrm{CO}_{2}$ concentrations during continental shelf mixing. (a) DIC concentration vs. salinity. On the x-axis, $S_{i}$ and $S_{\text {ocean }}$ are the salinities of station $i$ and the ocean end-member, respectively. On the y-axis, DIC $\mathrm{C}_{\text {ocean }}$, $\mathrm{DIC}_{\text {river+marsh }}$ and $\mathrm{DIC}_{\text {river }}$ are DIC concentrations of the oceanic end-member, nearshore end-member (containing DIC from both the river and marsh), and the river end-member, respectively. On the right side, $\mathrm{DIC}_{i}$ is the in situ DIC concentration, and $\mathrm{DIC}_{\mathrm{R}+\mathrm{M}}$, $\mathrm{DIC}_{\mathrm{R}}$, and $\mathrm{DIC}_{\text {base }}$ are the DIC concentrations at the salinity of $S_{i}$ assuming the ocean end-member is mixed only with the nearshore end-member (containing DIC from both the river and marsh), the river end-member, and zero-DIC freshwater end-member, respectively. (b) Dissolved $\mathrm{CO}_{2}$ concentrations vs. salinity. The corresponding $p \mathrm{CO}_{2}$ can be calculated according to $p \mathrm{CO}_{2}=k_{\mathrm{H}} \cdot\left(\mathrm{CO}_{2}\right)$, where $k_{\mathrm{H}}$ is Henry's constant.

and $\Delta p \mathrm{CO}_{2}$ (shelf). In addition, the nearshore end-members are not temporally stable relative to the residence time of the shelf, because primary production and respiration in the nearshore areas are highest and show the largest seasonal variation of the entire shelf (Griffith et al., 1990; Verity et al., 1993; Cai, unpublished data). This again will bring about large uncertainties (Loder and Reichard, 1981). 
Table 1. River, nearshore and open ocean end-members used in calculations described in Sect. 2.5. DIC and TA designate dissolved inorganic carbon and total alkalinity, respectively, with nits of $\mu \mathrm{mol} \mathrm{kg}{ }^{-1}$.

\begin{tabular}{lrrr|rrr|rrr}
\hline \multirow{2}{*}{ Month } & \multicolumn{3}{c}{ River end-member } & \multicolumn{3}{c|}{ Nearshore end-member } & \multicolumn{3}{c}{ Open ocean end-member } \\
\cline { 2 - 10 } & Salinity & DIC & TA & Salinity & DIC & TA & Salinity & DIC & TA \\
\hline Jan 2005 & 0.0 & 560.0 & 479.3 & 31.8 & 1943.2 & 2194.1 & 36.5 & 2040.0 & 2414.2 \\
Mar 2005 & 0.0 & 498.0 & 473.1 & 30.7 & 1896.3 & 2104.4 & 36.3 & 2077.3 & 2407.5 \\
May 2006 & 0.0 & 727.6 & 753.2 & 33.2 & 2019.8 & 2356.4 & 36.5 & 2070.3 & 2495.3 \\
Jul 2005 & 0.0 & 527.2 & 414.3 & 31.2 & 1994.6 & 2235.0 & 35.9 & 2016.5 & 2393.8 \\
Oct 2005 & 0.0 & 894.9 & 842.0 & 28.7 & 1908.9 & 2103.1 & 36.0 & 1985.4 & 2398.0 \\
\hline
\end{tabular}
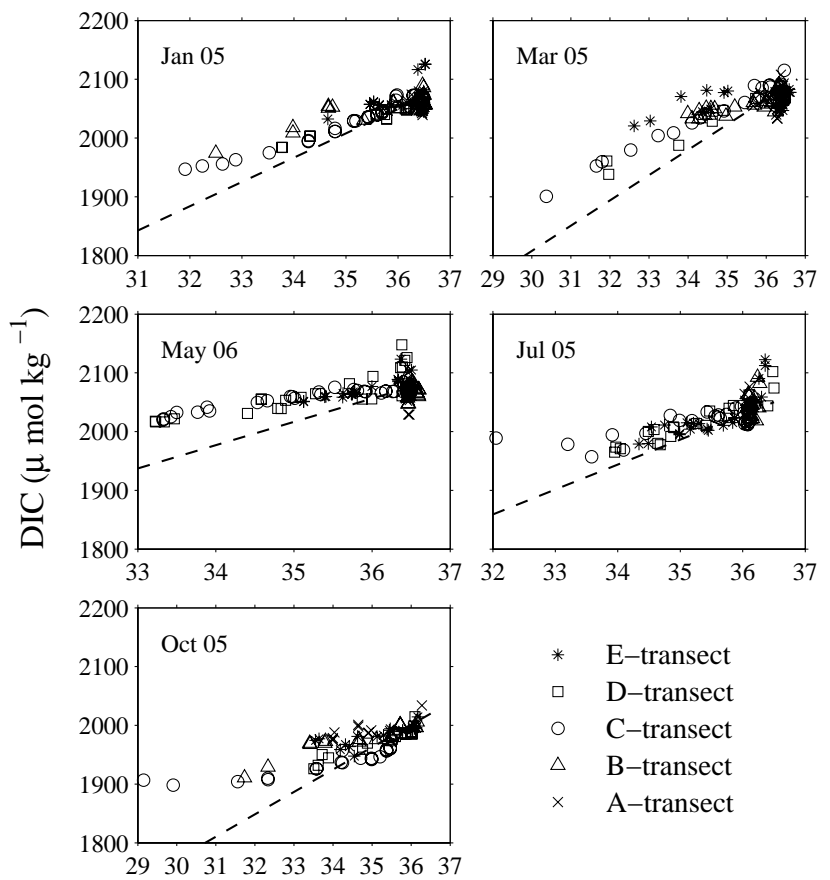

* E-transect

$\square \quad$ D-transect

O C-transect

$\triangle \quad$ B-transect

$\times \quad$ A-transect

Salinity

Fig. 3. Dissolved inorganic carbon (DIC) concentrations at depths shallower than $100 \mathrm{~m}$ vs. salinity and grouped by sampling month. The dotted lines connect the river and ocean end-members.

\section{Results}

\subsection{Dissolved inorganic carbon}

DIC concentrations in the SAB (i.e., $<100 \mathrm{~m}$ water depth) ranged from 1900 to $2100 \mu \mathrm{mol} \mathrm{kg}{ }^{-1}$ (Fig. 3). In all sampling months, DIC was lowest close to the coast and increased towards the shelf break. Nearshore DIC showed the largest seasonal variation, and was lowest in March and October 2005 when the shelf received the greatest amount of freshwater discharge. In comparison, DIC at the ocean endmember was relatively invariant with season. The nearshore DIC concentrations were higher than predicted from the conservative mixing line up to a salinity of 34 (Fig. 3).

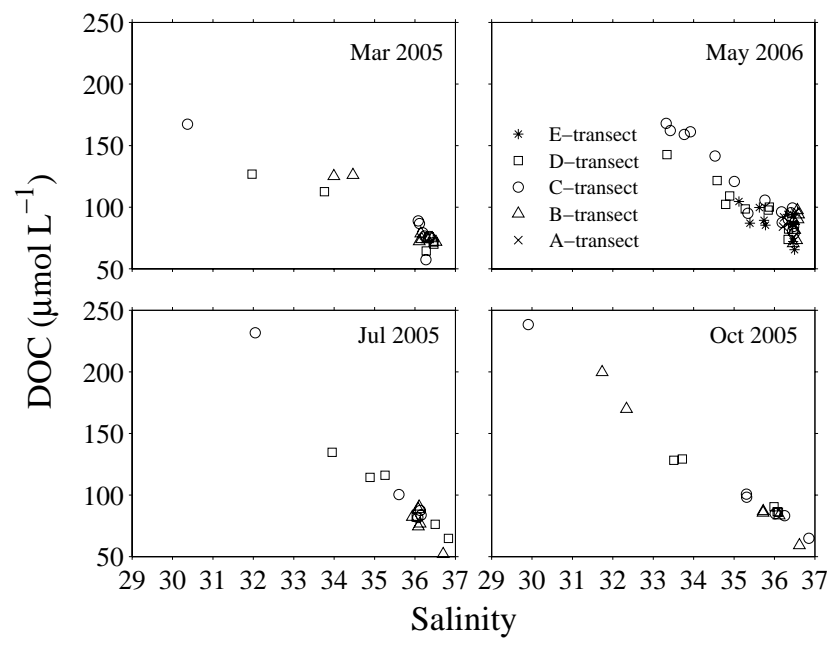

Fig. 4. Surface water dissolved organic carbon (DOC) vs. salinity in March, July, and October 2005 in the South Atlantic Bight.

\subsection{Dissolved organic carbon}

DOC concentrations in the SAB were negatively correlated with salinity (Fig. 4), indicating inputs of organic carbon from low salinity rivers and terrestrial sources. Spatially, the highest DOC concentrations occurred in the center (alongshore) of the inner shelf $\left(160-170 \mu \mathrm{mol} \mathrm{L}^{-1}\right.$ in March 2005 and May 2006, and $230-240 \mu \mathrm{mol} \mathrm{L}^{-1}$ in July and October 2005). Surface water DOC beyond the CFZ was much lower at $70-100 \mu \mathrm{mol} \mathrm{L}^{-1}$. In July 2005 unusually high DOC concentrations were observed in the outer SAB $\left(134 \mu \mathrm{mol} \mathrm{L}{ }^{-1}\right)$ off South Carolina where low salinity waters were observed (see Fig. 3, Jiang et al., 2008a).

\subsection{Impact of temperature on sea surface $p \mathrm{CO}_{2}$}

The annual temperature cycle throughout the SAB shelf resulted in lower $p \mathrm{CO}_{2}$ in winter and spring, and higher $p \mathrm{CO}_{2}$ in summer (Fig. 5). Area-averaged in situ $p \mathrm{CO}_{2}$ was undersaturated across the entire shelf during winter and spring, and increased into the summer months (Fig. 5). From May to October the shelf became super-saturated, with the inner shelf showing the highest $p \mathrm{CO}_{2}$. The magnitude of $\Delta p \mathrm{CO}_{2}$ (temp) 


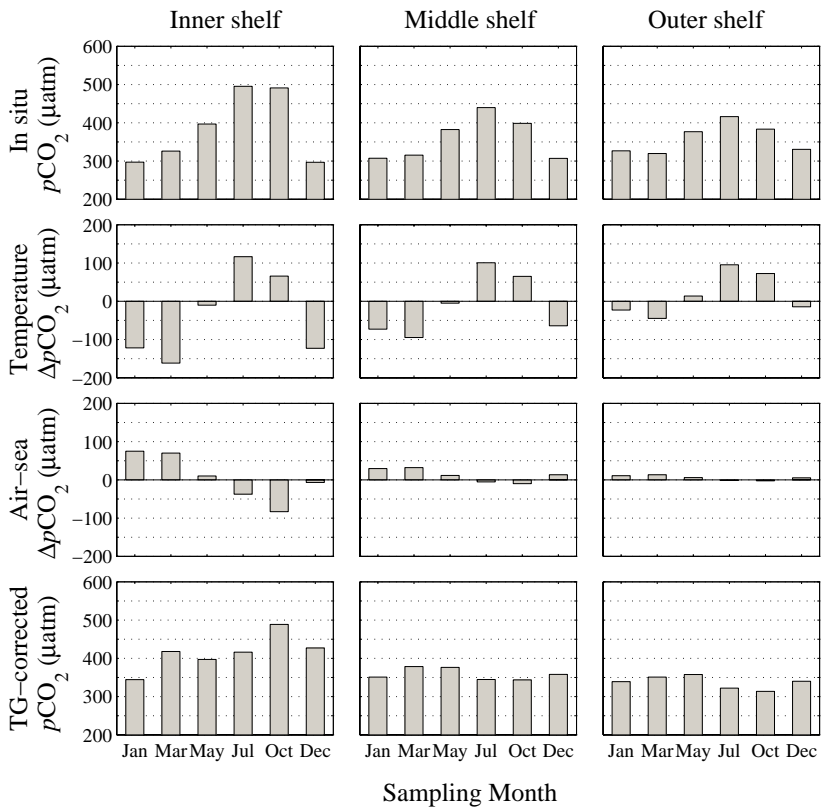

Fig. 5. Seasonal changes of area-averaged sea surface $p \mathrm{CO}_{2}, p \mathrm{CO}_{2}$ variations due to temperature deviation from the annual mean temperature $\left(23.11^{\circ} \mathrm{C}\right), p \mathrm{CO}_{2}$ variations due to air-sea gas exchange, and TG-corrected $p \mathrm{CO}_{2}$ on the $\mathrm{SAB}$. In situ $p \mathrm{CO}_{2}$ is the sum of $p \mathrm{CO}_{2}$ variations due to temperature, $p \mathrm{CO}_{2}$ variations due to airsea gas exchange, and TG-corrected $p \mathrm{CO}_{2}$ (see Eq. 1 in text).

on the inner shelf was larger than that on the outer shelf, partly due to the greater seasonal range of SST on the proximal SAB shelf $\left(10-30^{\circ} \mathrm{C}\right)$ compared with the distal SAB shelf $\left(20-30^{\circ} \mathrm{C}\right)$ (Jiang et al., 2008a).

\subsection{Impact of air-sea gas exchange on sea surface $\mathrm{pCO}_{2}$}

Air-sea gas exchange had the net effect of modulating the seasonal changes of $p \mathrm{CO}_{2}$ in the SAB. It increased $p \mathrm{CO}_{2}$ in winter when sea surface $p \mathrm{CO}_{2}$ was under-saturated and decreased it in summer when $p \mathrm{CO}_{2}$ was supersaturated (Fig. 5). However, while air-sea gas exchange played an important role in changing $p \mathrm{CO}_{2}$ on inner shelf, greater water depths and consequently greater integrated DIC inventory in the mixed layer on the outer shelf made air-sea gas exchange insignificant in controlling the $p \mathrm{CO}_{2}$ there (Fig. 5).

\subsection{TG-corrected $p \mathrm{CO}_{2}$}

During warm months (July and October 2005), when sea surface temperature (see Fig. 2 in Jiang et al., 2008a) was homogeneous over the entire $\mathrm{SAB}$ continental shelf, surface water TG-corrected $p \mathrm{CO}_{2}$ (Fig. 6) showed similar spatial distributions as in situ $p \mathrm{CO}_{2}$ (see Fig. 4 in Jiang et al., 2008a). Both were highest close to the coast and decreased with distance offshore. During winter (January, March, and December 2005), while TG-corrected $p \mathrm{CO}_{2}$ was still higher close

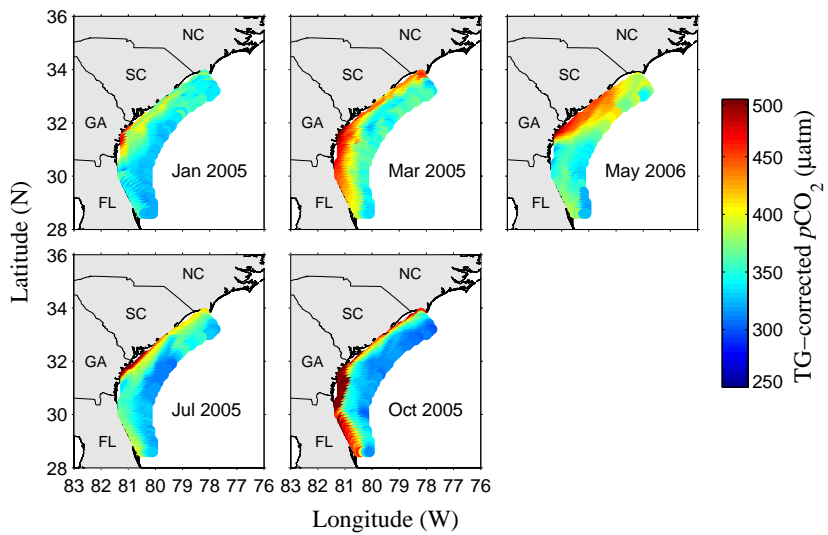

Fig. 6. Spatial distributions of surface water TG-corrected $p \mathrm{CO}_{2}$ in the South Atlantic Bight in all sampling months except December 2005. Due to a lack of DIC data, spatial distribution of TGcorrected $p \mathrm{CO}_{2}$ in December 2005 is not presented. The colored contours are from triangle-based liner interpolation.

to the coast than offshore, the trend was reversed for the in situ $p \mathrm{CO}_{2}$ (see Fig. 4 in Jiang et al., 2008a). The contrasting spatial variations in winter were due to the large onshoreoffshore temperature gradients at this time of the year (SST in winter was $\sim 10-14^{\circ} \mathrm{C}$ close to the coast and increased to $20-25^{\circ} \mathrm{C}$ at the shelf break; Jiang et al., 2008a).

The area-averaged TG-corrected $p \mathrm{CO}_{2}$ on the middle and outer shelf showed similar seasonal variation, i.e., increasing from January to March, leveling off in May, decreasing in July and October, and then increasing again in December (Fig. 5). On the inner shelf, the area-averaged TG-corrected $p \mathrm{CO}_{2}$ was lowest in January, and showed the largest increase in March and October (Fig. 5) when the shelf experienced the greatest river discharges.

\section{6 $\Delta p \mathrm{CO}_{2}$ (river), $\Delta p \mathrm{CO}_{2}(\mathrm{marsh})$, and $\Delta p \mathrm{CO}_{2}$ (shelf)}

As expected, contributions of $\mathrm{CO}_{2}$ from rivers $\left(\Delta p \mathrm{CO}_{2}\right.$ (river)) were highest close to the coast and decreased with distance offshore (Fig. 7). During January and March 2005, $\Delta p \mathrm{CO}_{2}$ (river) was up to $30 \mu \mathrm{atm}$ on the inner shelf but averaged only $0-3 \mu \mathrm{atm}$ on the outer shelf. Seasonally, $\Delta p \mathrm{CO}_{2}$ (river) was highest in January, March, and October 2005 (Fig. 8). Contributions of $\mathrm{CO}_{2}$ from salt marshes $\left(\triangle p \mathrm{CO}_{2}(\right.$ marsh $\left.)\right)$ showed similar spatial and seasonal distributions as $\Delta p \mathrm{CO}_{2}$ (river), with the magnitude of $\Delta p \mathrm{CO}_{2}$ (marsh) being about three times as high as that of $\triangle p \mathrm{CO}_{2}$ (river) (Figs. 8 and 9). Contributions of $\mathrm{CO}_{2}$ from within shelf waters $\left(\Delta p \mathrm{CO}_{2}\right.$ (shelf)) were highest of the three components (Figs. 8 and 10). Compared with $\Delta p \mathrm{CO}_{2}$ (river) and $\Delta p \mathrm{CO}_{2}$ (marsh), $\Delta p \mathrm{CO}_{2}$ (shelf) showed much smaller onshore-offshore gradients in January and March 2005. Seasonally, $\Delta p \mathrm{CO}_{2}$ (shelf) was highest in May 2006 and October 2005. 


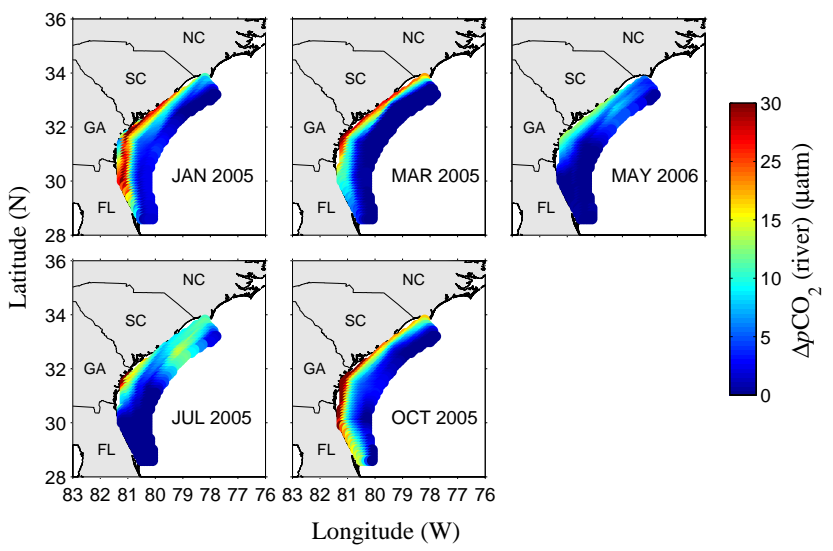

Fig. 7. Spatial distributions of $\Delta p \mathrm{CO}_{2}$ (river), or the portion of sea surface $p \mathrm{CO}_{2}$ that is due to inputs from the river (referenced to $23.11^{\circ} \mathrm{C}$ ). Due to a lack of DIC data, $\Delta p \mathrm{CO}_{2}$ (river) in December 2005 is not presented. The colored contours are from trianglebased liner interpolation.

\section{Discussion}

\subsection{Carbon inputs from terrestrial sources}

In addition to nutrients, continental shelves receive large amounts of organic and inorganic carbon from terrestrial sources. In the following discussion, "terrestrial" refers to all sources landward of the land/ocean boundary, including rivers, estuaries, salt marshes, groundwater, and other landderived sources. Inputs of organic carbon can be readily seen from the seaward decreases of DOC concentrations (Fig. 4). In contrast to DOC, DIC transport on the shelf is less obvious. DIC on the continental shelf contains a large oceanic component that may mask the DIC signal from terrestrial sources. Therefore, seaward increases in DIC concentrations do not necessarily indicate that the shelf is transporting DIC landward (Fig. 3). To examine the DIC inputs from terrestrial sources (as well as net ecosystem metabolism, or NEM), total excess DIC (DIC T-excess $_{\text {s }}$ ) was calculated according to Jiang et al. (2008b):

$\mathrm{DIC}_{\mathrm{T} \text {-excess }}=\mathrm{DIC}_{i}-\frac{S_{i}}{S_{\text {ocean }}} \times \mathrm{DIC}_{\text {ocean }}$

in $\mu \mathrm{mol} \mathrm{kg}{ }^{-1}$ or $\mathrm{mmol} \mathrm{m}^{-3}$, where $\mathrm{DIC}_{i}$ and $\mathrm{DIC}_{\text {ocean }}$ are DIC concentrations of station $i$ and the ocean end-member, respectively, and $S_{i}$ and $S_{\text {ocean }}$ are salinities of station $i$ and the ocean end-member, respectively. The second term on the right-hand side of Eq. (9) $\left(\frac{S_{\mathrm{i}}}{S_{\text {ocean }}} \times \mathrm{DIC}_{\text {ocean }}\right)$ represents the oceanic DIC component. Total excess DIC defined here represents all DIC sources or sinks (e.g., all terrestrial inputs as well as NEM on the shelf) except those from the open ocean.

The calculated total excess DIC was highest on the central part (alongshore) of the inner shelf $\left(140-180 \mu \mathrm{mol} \mathrm{kg}^{-1}\right)$ and lowest on the outer shelf $\left(-10\right.$ to $\left.50 \mu \mathrm{mol} \mathrm{kg}^{-1}\right)$ (Fig. 11). Like DOC, the total excess DIC shows negative correlation
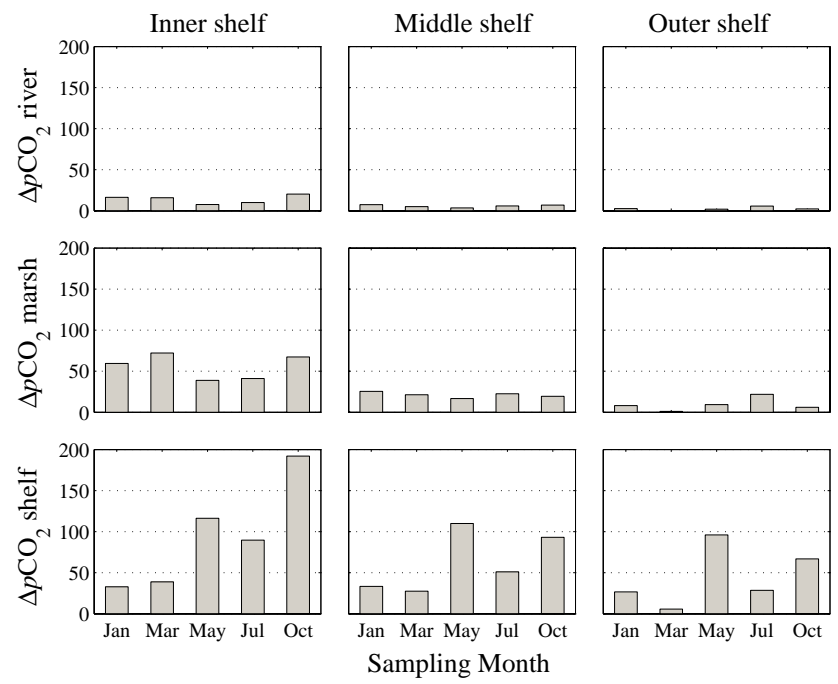

Fig. 8. Seasonal changes of area-averaged $\triangle p \mathrm{CO}_{2}$ (river), (referenced to $23.11^{\circ} \mathrm{C}$ ), $\Delta p \mathrm{CO}_{2}$ (marsh), and $\Delta p \mathrm{CO}_{2}$ (shelf).

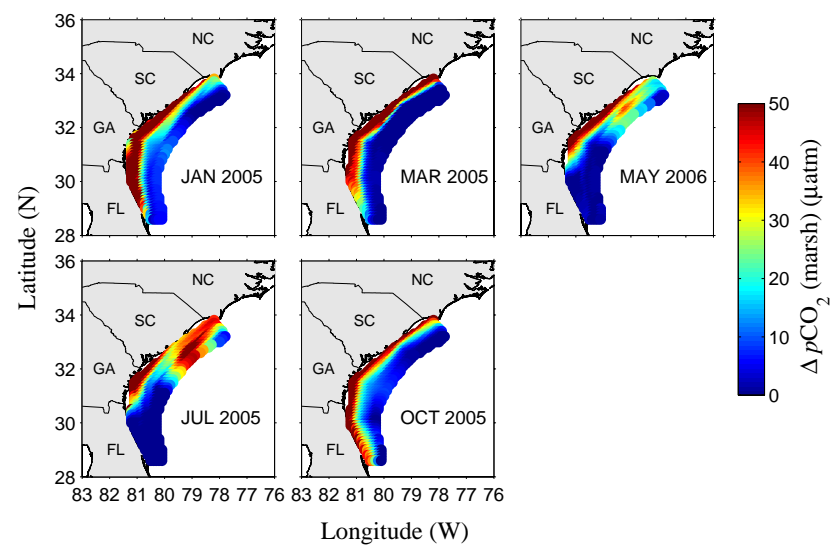

Fig. 9. Spatial distributions of $\Delta p \mathrm{CO}_{2}$ (marsh) (referenced to $23.11^{\circ} \mathrm{C}$ ). Due to a lack of DIC data, $\Delta p \mathrm{CO}_{2}$ (marsh) in December 2005 is not presented. The colored contours are from triangle-based liner interpolation.

with salinity in all sampling months, suggesting input of DIC from terrestrial sources (Fig. 11). Similarly, excess DOC was also calculated. Not surprisingly, excess DOC was also highest on the inner shelf and decreased with distance offshore (Fig. 12).

\subsection{Impact of terrestrial carbon on continental shelf $\mathrm{CO}_{2}$}

Even though the contribution of DIC from terrestrial sources is usually much smaller when compared with that from the open ocean, a larger proportion of the terrestrial DIC exists in the form of aqueous $\mathrm{CO}_{2}$. As a result, the input of terrestrial DIC plays a critical role in elevating $\mathrm{CO}_{2}$ concentrations in continental shelf waters. Terrestrial sources increase 


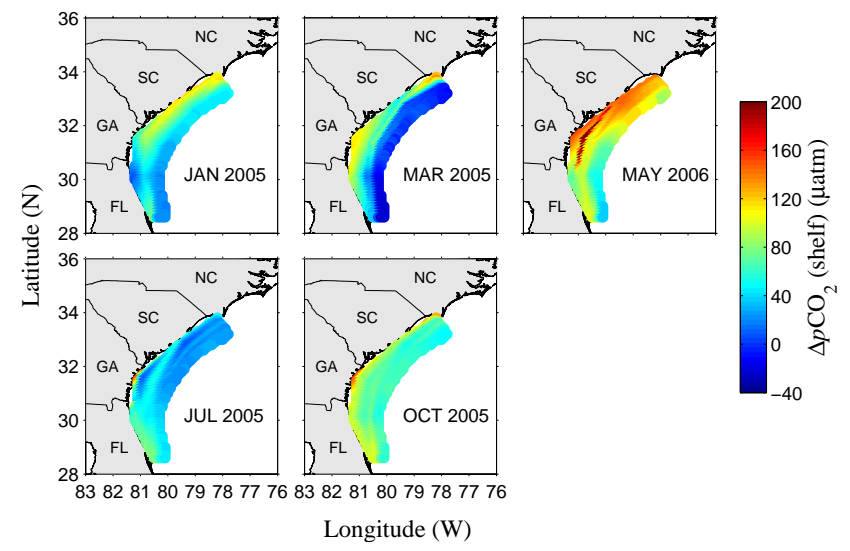

Fig. 10. Spatial distributions of $\Delta p \mathrm{CO}_{2}$ (shelf) (referenced to $23.11^{\circ} \mathrm{C}$ ). Due to a lack of DIC data, $\Delta p \mathrm{CO}_{2}$ (shelf) in December 2005 is not presented. The colored contours are from triangle-based liner interpolation.

nearshore $p \mathrm{CO}_{2}$ directly through input of inorganic carbon from rivers (Cai and Wang, 1998; Cai et al., 1999; Jiang et al., 2008b) and salt marshes (Wang and Cai, 2004), and indirectly by input of organic carbon (Moran et al., 1991; Alberts and Takács, 1999; DeAlteris, 2007) that is later remineralized to varying extents on the shelf as part of the shelf NEM.

Rivers discharging to the $\mathrm{SAB}$ enhance $p \mathrm{CO}_{2}$ in shelf waters by delivering freshwater with high $\mathrm{CO}_{2}$ concentrations that arise ultimately from microbial decomposition of organic matter in soils, river waters, and sediments (Jones and Mulholland, 1998; Neal et al., 1998; Cole and Caraco, 2001). Studies of the Altamaha and Satilla river estuaries have shown that rivers discharging to the SAB are highly supersaturated with respect to atmospheric $\mathrm{CO}_{2}$. During summer, surface water $p \mathrm{CO}_{2}$ in these river-dominated estuaries is as high as $\sim 4000 \mu$ atm compared with only about $\sim 400-600 \mu \mathrm{atm}$ on the continental shelf (Cai and Wang, 1998; Jiang et al., 2008b).

Salt marshes contribute to $p \mathrm{CO}_{2}$ in the $\mathrm{SAB}$ by direct release of inorganic carbon to the shelf. An important feature of this region is the extensive areas of inter-tidal salt marshes (Pomeroy and Wiegert, 1981). The dominant primary producer in these marshes is Spartina alterniflora, which has among the highest primary productivity of any ecosystem ( $\sim 1100$ to $2250 \mathrm{gC} \mathrm{m}^{-2} \mathrm{yr}^{-1}$; Dai and Wiegert, 1996). $\mathrm{CO}_{2}$ that is released to intertidal marsh sediments and waters by bacterial remineralization of Spartina-derived organic matter can be exported to coastal waters (Cai et al., 1999; Wang and Cai, 2004; Jiang et al., 2008b) via tidal flushing (Neubauer and Anderson, 2003) and drainage of sediment interstitial waters (Jahnke et al., 2003).

Rivers and salt marshes also transport significant amounts of organic carbon to the SAB (Fig. 12), the remineralization of which by microbes (Pomeroy et al., 2000; Jahnke et al., 2005) and photochemistry (Miller and Moran, 1997) in

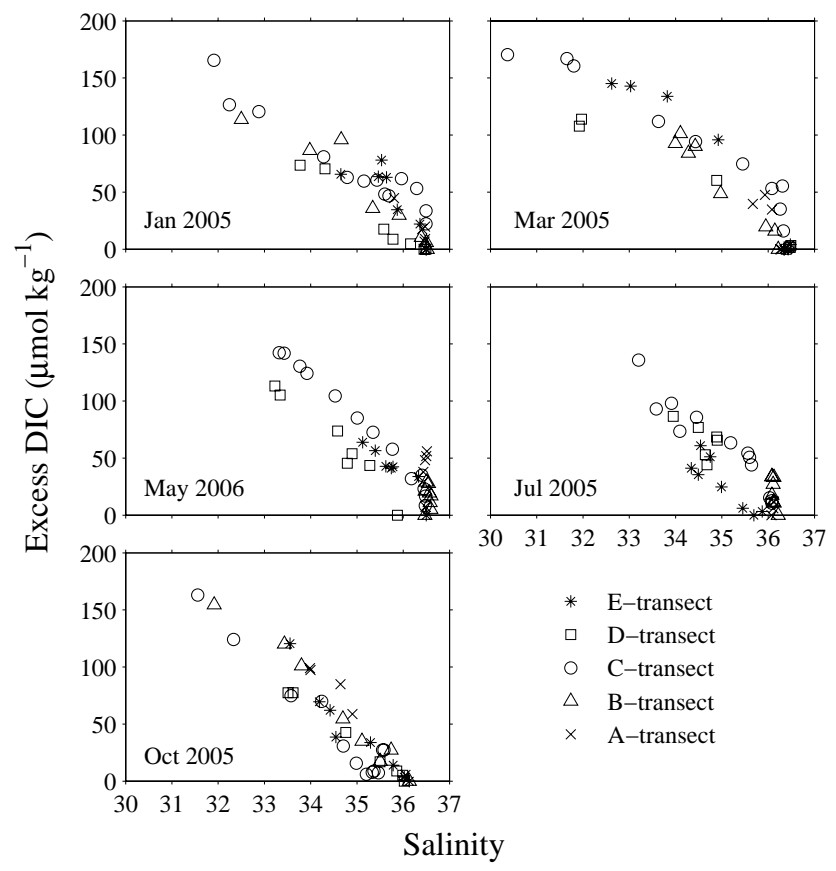

Fig. 11. Surface water total excess DIC (in excess of DIC from oceanic sources) plotted against salinity in January, March, July, October 2005 and May 2006 in the South Atlantic Bight. Due to lack of data, total excess DIC in December 2005 was not calculated.

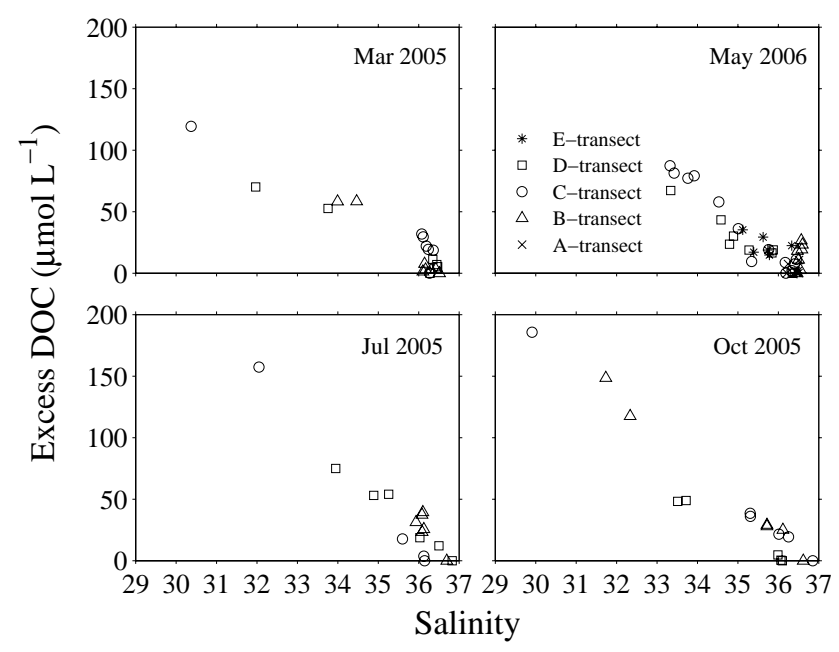

Fig. 12. Surface water excess DOC (i.e., DOC in excess of that from oceanic sources) vs. salinity in March, July, October 2005 and May 2006 in the South Atlantic Bight. Due to a lack of data, excess DOC in January and December 2005 was not calculated.

shelf waters and sediments will further increase the nearshore $p \mathrm{CO}_{2}$. Previous studies have shown that most nutrients entering the SAB occur in organic form that must be remineralized before they may be taken up by phytoplankton (Dunstan and Atkinson, 1976; Hanson et al., 1990; DeAlteris, 2007). The potential importance of this pathway in enhancing $p \mathrm{CO}_{2}$ 
on the proximal $\mathrm{SAB}$ is supported by the positive correlation between TG-corrected $p \mathrm{CO}_{2}$ and excess DOC (figure not shown).

\subsection{Seasonal changes of $\mathrm{CO}_{2}$ inputs to the proximal SAB}

Seasonally, $\mathrm{CO}_{2}$ from the $\mathrm{SAB}$ rivers and salt marshes is largely related to river discharge rates, and greater amounts of $\mathrm{CO}_{2}$ will be transported to the shelf at higher discharge rates (Borges et al., 2006; Jiang et al., 2008b). This can be seen from the higher $\Delta p \mathrm{CO}_{2}$ (river) and $\Delta p \mathrm{CO}_{2}$ (marsh) during January and March 2005 (high flow seasons, Jiang, 2009) than in May 2006 and July 2005 (low flow seasons) (Fig. 8).

Based on the findings from the present study, $\mathrm{CO}_{2}$ production from within shelf waters (e.g., NEM), on the other hand, is predicted to be strongly dependent on temporal changes in organic matter remineralization and shelf water residence time. Respiration rates in the inner shelf have been shown to be nearly an order of magnitude higher in summer and fall than in winter and spring (Hopkinson, 1985; Griffith et al., 1990; Jiang et al., 2010). However, the additional $\mathrm{CO}_{2}$ released from heterotrophic processes in summer may be counterbalanced by greater $\mathrm{CO}_{2}$ uptake due to aquatic primary production at this time of the year (Verity et al., 2002). The results of $\Delta p \mathrm{CO}_{2}$ (shelf) suggest that the shelf is more likely to be heterotrophic (i.e., net release of $\mathrm{CO}_{2}$ ) during summer and fall (May 2006, July and October 2005), and relatively more autotrophic (i.e., net uptake of $\mathrm{CO}_{2}$ ) during winter and spring (January and March 2005) (Fig. 8). This is confirmed by the $\delta^{13}$ values of DIC in the proximal SAB, which became increasingly depleted between spring and fall (DeAlteris, 2007). The relatively lower $\mathrm{CO}_{2}$ production during July 2005 may be further related to a Gulf Stream intrusion, which increased biological production and counterbalanced the DIC production.

\section{Conclusions}

Analyses of the DIC, DOC, and $p \mathrm{CO}_{2}$ data in the $\mathrm{SAB}$ demonstrate how temperature, air-sea gas exchange, and terrestrial inputs control sea surface $p \mathrm{CO}_{2}$ on the continental shelf. Terrestrial sources increase the nearshore $p \mathrm{CO}_{2}$ by direct input of inorganic carbon from rivers and salt marshes, and indirectly by input of organic carbon that is later remineralized in the SAB (i.e., shelf NEM). This mechanism is the most likely explanation for findings of the proximal SAB (inner shelf) being a source of atmospheric $\mathrm{CO}_{2}$ $\left(+1.2 \mathrm{~mol} \mathrm{~m}^{2} \mathrm{yr}^{-1}\right)$, and the distal SAB (middle and outer shelf) being a sink of $-1.3 \mathrm{~mol} \mathrm{~m}^{2} \mathrm{yr}^{-1}$ (Jiang et al., 2008a). In particular, decomposition of marsh- and river-derived organic carbon is the most important factor in maintaining the high $p \mathrm{CO}_{2}$ on the inner shelf during the fall.
Acknowledgements. This work was supported by a National Science Foundation (NSF) grant (OCE-0425153) and a National Oceanic and Atmospheric Administration (NOAA) grant (NA050AR4311161) to W.-J. Cai, and by a NSF Chemical Oceanography Program grant (OCE-0327423) and a Integrated Carbon Cycle Research Program grant (EAR-0403949) to J. Bauer. Sampling was conducted on the $\mathrm{R} / \mathrm{V}$ Cape Hatteras and $\mathrm{R} / \mathrm{V}$ F. G. Walton Smith. We thank Jennifer DeAlteris, Cedric Fichot, and William L. Miller for DOC analysis. We benefited from the discussion with Rik Wanninkhof, Charles S. Hopkinson, and William L. Miller. We also want to thank G. Han for laboratory support; Heike Lüger, Feizhou Chen, Justin Hartmann, Xianghui Guo, and Longjun Zhang for help with data collection during some of the cruises. Comments from C. T. Arthur Chen and an anonymous reviewer were very helpful.

Edited by: M. Dai

\section{References}

Alberts, J. J. and Takács, M.: Importance of humic substances for carbon and nitrogen transport into southeastern United States estuaries, Organic Geochem., 30, 385-395, 1999.

Alexander, C. E., Broutman, M. A., and Field, D. W.: An Inventory of Coastal Wetlands of the USA, NOAA, US Department of Commerce, Washington, DC, 1986.

Atkinson, L. P., Blanton, J. O., and Haines, E.: Shelf flushing rates based on the distribution of salinity and freshwater in the Georgia Bight, Estuar. Coast. Shelf S., 7, 465-472, 1978.

Atkinson, L. P., Yoder, J. A., and Lee, T. N.: Review of upwelling off the southeastern United States and its effect on continentalshelf nutrient concentrations and primary productivity, Rapp. P.v. Cons. Int. Explor. Mer, 183, 70-78, 1984.

Bauer, J. E. and Bianchi, T. S.: Dissolved Organic Carbon Cycling and Transformation, in: Treatise on Estuarine and Coastal Science, edited by: Wolanski, E. and McLusky, D. S., Biogeochemistry, 5, 7-67, Waltham, Academic Press, 2011.

Bianchi, T. S. and Bauer, J. E.: Particulate Organic Carbon Cycling and Transformation, in: Treatise on Estuarine and Coastal Science, edited by: Wolanski, E. and McLusky, D. S., Biogeochemistry, 5, 69-117, Waltham, Academic Press, 2011.

Blanton, J. O.: Ocean currents along a nearshore frontal zone on the continental shelf of the southeastern United States, J. Phys. Oceanogr., 11, 1627-1637, 1981.

Borges, A. V., Djenidi, S., Lacrois, G., Théate, J.-M., Delille, B., and Frankignoulle, M.: Atmospheric $\mathrm{CO}_{2}$ flux from mangrove surrounding waters, Geophys. Res. Lett., 30, 1558, doi:10.1029/2003GL017143, 2003.

Borges, A. V., Delille, B., and Frankignoulle, M.: Budgeting sinks and sources of $\mathrm{CO}_{2}$ in the coastal ocean: diversity of ecosystems counts, Geophys. Res. Lett., 32, doi:10.1029/2005GL023053, 2005.

Borges, A. V., Schiettecatte, L.-S., Abril, G., Delille, B., and Gazeau, F.: Carbon dioxide in European coastal waters, Estuar. Coast. Shelf S., 70, 375-387, 2006.

Cai, W.-J. and Wang, Y.: The chemistry, fluxes, and sources of carbon dioxide in the estuarine waters of the Satilla and Altamaha Rivers, Georgia, Limnol. Oceanogr., 43, 657-668, 1998. 
Cai, W.-J., Pomeroy, L. R., Moran, M. A., and Wang, Y.: Oxygen and carbon dioxide mass balance for the estuarine-intertidal marshe complex of five rivers in the southeastern U.S., Limnol. Oceanogr., 44, 639-649, 1999.

Cai, W.-J., Dai, M., and Wang, Y.: Air-sea exchange of carbon dioxide in ocean margins: A province-based synthesis, Geophys. Res. Lett., 33, L12603, doi:10.1029/2006GL026219, 2006.

Cai, W.-J., Hu, X., Huang, W.-J., Jiang, L.-Q., Wang, Y., Peng, T. H., and Zhang, X.: Alkalinity distribution in the western North Atlantic Ocean margins, J. Geophys. Res., 115, C08014, doi:10.1029/2009JC005482, 2010.

Chen, C.-T. A. and Borges, A. V.: Reconciling opposing views on carbon cycling in the coastal ocean: continental shelves as sinks and near-shore ecosystems as sources of atmospheric $\mathrm{CO}_{2}$, Deep-Sea Res. II, 56, 578-590, 2009.

Cole, J. J. and Caraco, N. F.: Carbon in catchments: connecting terrestrial carbon losses with aquatic metabolism, Mar. Freshwater Res., 52, 101-110, 2001.

Dai, T. and Wiegert, R. G.: Estimation of the primary productivity of Spartina alterniflora using a canopy model, Ecography, 19, 410423, 1996.

de Hass, H., van Weering, T. C. E., and de Stigter, H.: Organic carbon in shelf seas: sinks or sources, processes and products, Cont. Shelf Res., 22, 691-717, 2002.

DeAlteris, J. A.: Elemental and isotopic characterization of organic matter and carbon in the South Atlantic Bight, College of William \& Mary, Williamsburg, Virginia, 196 pp., 2007.

Dunstan, W. M. and Atkinson, L. P.: Sources of new nitrogen for the South Atlantic Bight, in: Estuarine Processes I, Uses, Stresses, and Adaptation to the Estuary, edited by: Wiley, M., Academic Press, New York, 69-78, 1976.

Gattuso, J.-P., Frankignoulle, M., and Wollast, R.: Carbon and carbonate metabolism in coastal aquatic ecosystems, Annu. Rev. Ecol. Syst., 29, 405-434, 1998.

Griffith, P. C., Douglas, D. J., and Wainright, S. C.: Metabolic activity of size-fractionated microbial plankton in estuarine, nearshore, and continental shelf waters of Georgia, Mar. Ecol.Prog. Ser., 59, 263-270, 1990.

Hanson, R. B., Robertson, C. Y., Yoder, J. A., Verity, P. G., and Bishop, S. S.: Nitrogen recycling in coastal waters of southeastern U.S. during summer 1986, J. Mar. Res., 48, 641-660, 1990.

Hopkinson, C. S.: Shallow-water benthic and pelagic metabolism: evidence of heterotrophy in the nearshore Georgia Bight, Mar. Biol., 87, 19-32, 1985.

Huang, W.-J., Wang, Y., and Cai, W.-J.: Assessment of sample storage techniques for total alkalinity and dissolved inorganic carbon in seawater, Limnol. Oceanogr.-Meth., 10, 711-717, 2012.

Jahnke, R. A., Alexander, C. R., and Kostka, J. E.: Advective pore water input of nutrients to the Satilla River Estuary, Georgia, USA, Estuar. Coast. Shelf S., 56, 641-653, 2003.

Jahnke, R., Richards, M., Nelson, J., Robertson, C., Rao, A., and Jahnke, D.: Organic matter remineralization and porewater exchange rates in permeable South Atlantic Bight continental shelf sediments, Cont. Shelf Res., 25, 1433-1452, 2005.

Jiang, L.-Q.: Biogeochemical cycling of carbon dioxide in estuaries and the continental shelf of the southeastern United States, Ph.D, Marine Science, University of Georgia, Athens, 172 pp., 2009.

Jiang, L.-Q., Cai, W.-J., Wanninkhof, R., Wang, Y., and Lüger, H.: Air-sea $\mathrm{CO}_{2}$ fluxes on the U.S. South Atlantic Bight: spa- tial and seasonal variability, J. Geophys. Res., 113, C07019, doi:10.1029/2007JC004366, 2008a.

Jiang, L.-Q., Cai, W.-J., and Wang, Y.: A comparative study of carbon dioxide degassing in river- and marine-dominated estuaries, Limnol. Oceanogr., 53, 2603-2615, 2008 b.

Jiang, L.-Q., Cai, W.-J., Wang, Y., Diaz, J., Yager, P., and Hu, X.: Pelagic community respiration on the continental shelf off Georgia, USA, Biogeochemistry, 98, 101-113, 2010.

Jones, J. B. and Mulholland, P. J.: Carbon dioxide variation in a hardwood forest stream: an integrative measure of whole catchment soil respiration, Ecosystems, 1, 183-196, 1998.

Loder, T. C. and Reichard, R. P.: The dynamics of conservative mixing in estuaries, Estuaries, 4, 64-69, 1981.

Mackenzie, F. T.: What is the importance of ocean margin processes in Global Change, in: Phys. Ch. Ear., edited by: Mantoura, R. F. C., Martin, J.-M., and Wollast, R., John Wiley and Sons, N.Y., 433-454, 1991.

Menzel, D. W.: Ocean Processes: U. S. Southeast Continental Shelf, U.S. Department of Energy, 112 pp., 1993.

Miller, W. L., and Moran, M. A.: Interaction of photochemical and microbial processes in the degradation of refractory dissolved organic matter from a coastal marine environment, Limnol. Oceanogr., 42, 1317-1324, 1997.

Moore, W. S.: Seasonal distribution and flux of radium isotopes on the Southeastern U.S. Continental Shelf, J. Geophys. Res., 112, C10013, doi:10.1029/2007JC004199, 2007.

Moran, M. A., Pomeroy, L. R., Sheppard, E. S., Atkinson, L. P., and Hodson, R. E.: Distribution of terrestrial derived dissolved organic matter on the southeastern U.S. continental shelf, Limnol. Oceanogr., 36, 1134-1149, 1991.

Neal, C., House, W. A., Jarvie, H. P., and Eartherall, A.: The significance of dissolved carbon dioxide in major lowland rivers entering the North Sea, Sci. Total Environ., 210-211, 187-203, 1998.

Nelson, J. R., Eckman, J. E., Robertson, C. Y., Marinelli, R. L., and Jahnke, R. A.: Benthic microalgal biomass and irradiance at the sea floor on the continental shelf of the South Atlantic Bight: spatial and temporal variability and storm effects, Cont. Shelf Res., 19, 477-505, 1999.

Neubauer, S. and Anderson, I. C.: Transport of dissolved inorganic carbon from a tidal freshwater marsh to the York River estuary, Limnol. Oceanogr., 48, 299-307, 2003.

Pomeroy, L. R. and Wiegert, R. G.: The Ecology of a Salt Marsh, Springer-Verlag, New York, 1981.

Pomeroy, L. R., Sheldon, J. E., Sheldon, W. M., Blanton, J. O., Amft, J., and Peters, F.: Seasonal changes in microbial processes in estuarine and continental shelf waters of the south-eastern $U$. S. A., Estuar. Coast. Shelf S., 51, 415-428, 2000.

Rabouille, C., Mackenzie, F. T., and Ver, L. M.: Influence of the human perturbation on carbon, nitrogen, and oxygen biogeochemical cycles in the global coastal ocean, Geochim. Cosmochim. Ac., 65, 3615-3641, 2001.

Raymond, P. A., Bauer, J. E., and Cole, J. J.: Atmospheric $\mathrm{CO}_{2}$ evasion, dissolved inorganic carbon production, and net heterotrophy in the York River estuary, Limnol. Oceanogr., 45, 17071717, 2000.

Riebesell, U., Fabry, V. J., Hansson, L., and Gattuso, J.-P.: Guide to best practices for ocean acidification research and data reporting, 258 pp., 2010. 
Smith, S. V. and Hollibaugh, J. T.: Coastal metabolism and the oceanic organic carbon balance, Rev. Geophys., 31, 75-89, 1993.

Takahashi, T., Olafsson, J., Goddard, J. G., Chipman, D. W., and Sutherland, S. C.: Seasonal variation of $\mathrm{CO}_{2}$ and nutrients in the high-latitude surface oceans: a comparative study, Global Biogeochem. Cy., 7, 843-878, 1993.

Takahashi, T., Sutherland, S. C., Sweeney, C., Poisson, A., Metzl, N., Tilbrook, B., Bates, N., Wanninkhof, R., Feely, R. A., Sabine, C., Olafsson, J., and Nojiri, Y.: Global sea-air $\mathrm{CO}_{2}$ flux based on climatological surface ocean $p \mathrm{CO}_{2}$, and seasonal biological and temperature effects, Deep-Sea Res. II, 49, 1601-1622, 2002.

Thomas, H., Bozec, Y., Elkalay, K., and De Baar, H. J. W.: Enhanced open ocean storage of $\mathrm{CO}_{2}$ from shelf sea pumping, Science, 304, 1005-1008, 2004.

Verity, P. G., Bishop, S. S., Nelson, J. R., Craven, D. B., Blanton, J. O., Robertson, C. Y., and Tronzo, C. R.: Composition, productivity, and nutrient chemistry of a coastal ocean planktonic food web, Cont. Shelf Res., 13, 741-776, 1993.
Verity, P. G., Redalje, D. G., Lohrenz, S. R., Flagg, C., and Hristov, R.: Coupling between primary production and pelagic consumption in temperate ocean margin pelagic ecosystems, Deep-Sea Res. II, 49, 4553-4569, 2002.

Walsh, J. J.: On the Nature of Continental Shelves, Academic, San Diego, 1988.

Wang, Z. and Cai, W.-J.: Carbon dioxide degassing and inorganic carbon export from a marsh dominated estuary (the Duplin River): A marsh $\mathrm{CO}_{2}$ pump, Limnol. Oceanogr., 49, 341-352, 2004.

Wollast, R.: Interactions of carbon and nitrogen cycles in the coastal zone, in: Interactions of C, N, P and S Biogeochemical Cycles and Global Change, edited by: Wollast, R., Mackenzie, F. T., and Chou, L., Springer, Berlin, 195-210, 1993. 